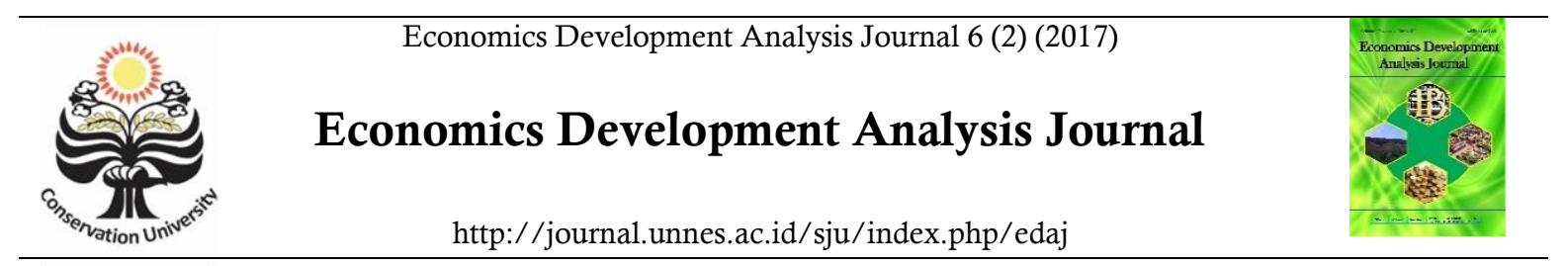

\title{
Implementasi Kebijakan Pungutan Biaya di SD N 02 Pododadi Kabupaten Pekalongan
}

\section{Lilik Elisah Milyani $^{1 凶}$, Bambang Prishardoyo $^{2}$}

Jurusan Ekonomi Pembangunan, Fakultas Ekonomi, Universitas Negeri Semarang.

\begin{tabular}{|c|c|}
\hline Info Artikel & Abstrak \\
\hline $\begin{array}{l}\text { Sejarah Artikel: } \\
\text { Diterima Januari } 2017\end{array}$ & \multirow{5}{*}{$\begin{array}{l}\text { Tujuan penelitian ini untuk mengetahui dan menjelaskan mengenai adanya pungutan biaya pada } \\
\text { pendidikan dasar. Teknik pengumpulan data yaitu observasi, wawancara, dan dokumentasi. Uji } \\
\text { Keabsahan data menggunakan triangulasi. Hasil dari penelitian ini adalah adanya pungutan biaya } \\
\text { pendidikan yang terjadi pada satuan pendidikan dasar yang seharusnya sudah tidak diperbolehkan, } \\
\text { dengan adanya peraturan menteri pendidikan dan kebudayaan mengenai adanya pungutan dan } \\
\text { sumbangan. Sumbangan yang dilakukan oleh sekolah digunakan untuk memperbaiki pembangunan } \\
\text { gedung sekolah. Dalam hal ini sekolah untuk tidak diperbolehkan melakukan pungutan, akan tetapi } \\
\text { boleh melakukan adanya sumbangan yang sifatnya tidak mengikat atau sukarela. Akan tetapi } \\
\text { sekolah melakukan sumbangan dengan tata cara yang salah. Tata cara yang dilakukan oleh sekolah } \\
\text { untuk sumbangan tersebut bersifat wajib, mengikat, serta jumlah nominal dan waktunya ditentukan } \\
\text { oleh satuan pendidikan. Sehingga hal ini yang disebut dengan pungutan bukan sumbangan yang } \\
\text { tidak diperbolehkan atau dilarang. Sumbangan tersebut dilakukan rapat yang hanya dihadiri oleh } \\
\text { guru beserta komite sekolah saja, tanpa melibatkan pihak pemerintah kabupaten maupun orang tua } \\
\text { peserta didik. }\end{array}$} \\
\hline Disetujui Maret 2017 & \\
\hline Dipublikasikan Mei 2017 & \\
\hline $\begin{array}{l}\text { Keywords: } \\
\text { Policy Implementation, } \\
\text { charges the education cost, } \\
\text { regional Autonomy. }\end{array}$ & \\
\hline & \\
\hline
\end{tabular}

\begin{abstract}
The purpose of this research to identify and explain the charge fees on basic education. Data collection techniques were observation, interviews, and documentation. Test the validity of the data using triangulation. The results of this study were charge education costs that occurred at the unit basic education should no longer be allowed, with the regulation of the minister of education and culture of the charge and donations. Donations carried by the school used to improve the construction of school buildings. In this case the school was not allowed to charge any fees, but must do their non-binding nature donations or volunteering. But schools do contribute in a manner that is incorrect. Procedures to do by the school for the donation was mandatory, binding, and the nominal amount and timing determined by the education unit. So this was called the charges instead of donations that were not allowed or prohibited. The donations were to do only meeting which was attended by teachers and their school committees only, without involving the government district and the parents of students.
\end{abstract}

\footnotetext{
$\bowtie$ Alamat korespondensi:

Gedung L2 Lantai 2 FE Unnes

Kampus Sekaran, Gunungpati, Semarang, 50229

E-mail: liliklisamilyani@gmail.com
} ISSN 2252-6765 


\section{PENDAHULUAN}

Pelaksanaan otonomi daerah sejak adanya Undang-Undang Republik Indonesia Nomor 22 Tahun 1999 yang mengatur tentang pemerintahan daerah yang di gantikan oleh Undang-Undang Republik Indonesia Nomor 32 Tahun 2004 tentang Pemerintahan Daerah, yang kemudian di gantikan dengan Undang-Undang Republik Indonesia Nomor 23 Tahun 2014 tentang Pemerintahan Daerah yang menyatakan bahwa penyelenggaraan pemerintahan daerah diarahkan untuk mempercepat terwujudnya kesejahteraan masyarakat melalui peningkatan pelayanan, pemberdayaan dan peran serta masyarakat, serta meningkatkan daya saing daerah dengan memperhatikan prinsip demokrasi, pemerataan, keadilan dan kekhasan suatu daerah, sebagai pengganti Undang-Undang Pemerintahan daerah tahun 2004. Pemerintah mengeluarkan Undang-Undang terbaru Nomor 9 tahun 2015 yang merupakan perubahan kedua atas Undang-Undang Nomor 23 tahun 2014 tentang pemerintahan daerah.

Sektor pendidik merupakan sektor dalam desentralisasi yang terkandung dalam UndangUndang Nomor 23 Tahun 2014 yang didalamnya menjelaskan mengenai pemerintahan daerah, Pelaksanaan desentralisasi pendidikan adanya pelimpahan wewenang dalam penyelengaraan pendidikan dari pusat ke daerah. Tanggung jawab, tugas dan wewenang pemerintah pusat atau provinsi dilimpahkan ke pemerintah kabupaten/kota. Dengan adanya pelimpahan wewenang, pemerintah harus bertanggung jawab dan responsif terhadap pemerintahan (Faguet, 2014). Pelaksanaan otonomi daerah dalam pendidikan harus bersifat accountable, yang artinya kebijakan pendidikan yang diambil harus selalu dipertanggungjawabkan kepada publik, karena sekolah merupakan institusi publik atau lembaga yang melayani kebutuhan masyarakat. Untuk mencapai tujuan pengembangan pendidikan, perlu adanya optimalisasi pengelolaan desentralisasi pendidikan (Laudams, 2014). Otonomi tanpa disertai dengan akuntabilitas publik bisa menjadi tindakan yang sewenang-wenang.
Dalam aspek kewenangan pendidikan menjadi tanggungjawab Pemerintah Daerah. Hal itu secara tegas dinyatakan dalam UU No.32 Tahun 2004 tentang Sistem Pemerintahan Daerah khususnya pasal 13 dan 14 yang menyatakan bahwa penyelenggaraan pendidikan menjadi tanggungjawab pemerintah daerah. Dalam pasal 10 Undang-undang yang sama menyatakan bahwa urusan pusat (absolut) hanyalah persoalan politik luar negeri, pertahanan keamanan, yustisi, moneter/fiskal, dan agama. Jadi selayaknya jika Pemerintah Daerah megambil peran yang besar dalam memajukan pendidikan di daerahnya masing-masing, tidak terkecuali madrasah/ swasta.

Otonomi pendidikan menurut UndangUndang Sistem Pendidikan Nasional Nomor 20 tahun 2003 adalah terungkap pada Hak dan Kewajiban Warga Negara, Orang tua, Masyarakat dan Pemerintah. Pada bagian ketiga Hak dan Kewajiban pasal 8 disebutkan bahwa "Masyarakat berhak berperan serta dalam perencanaan, pelaksanaan, pengawasan dan evaluasi program pendidikan; pasal 9 Masyarakat berkewajiban memberikan dukungan sumber daya dalam penyelenggaraan pendidikan". Begitu juga pada bagian keempat Hak dan Kewajiban Pemerintah dan Pemerintah daerah, pada pasal 11 ayat (2) bahwa " Pemerintah dan Pemerintah Daerah wajib menjamin terjadinya dan guna terselenggaranya pendidikan bagi Warga Negara yang berusia tujuh sampai lima belas tahun ".

Pendidikan pada awalnya adalah suatu proses penyempurnaan harkat dan martabat manusia yang diupayakan secara terus menerus. Di mana pun proses pendidikan terjadi, menunjukkan bahwa pendidikan mempunyai nilai-nilai yang dalam, karena jika kita berbicara pendidikan pada hakekatnya membicarakan harkat dan martabat serta nilai-nilai kemanusiaan. kemudian pada era otonomi daerah Pemerintah memberlakukan adanya otonomi pendidikan yang merupakan pemberlakuan sistem desentralisasi akibat adanya pemberlakuan UndangUndang tentang otonomi daerah yang memberikan dampak terhadap pelaksanaan pendidikan yaitu memberi ruang gerak yang lebih luas kepada 
pemerintah daerah untuk mengelola pendidikan dalam mencapai output pendidikan yang berkualitas dan mandiri.

Sejak dilaksanakannya otonomi pendidikan, ternyata pelaksanaannya belum berjalan sebagaimana yang diharapkan namun pemberlakuan otonomi membuat banyak masalah pada pendidikan yaitu mahalnya biaya pendidikan. Sedangkan pengertian otonomi pendidikan sesungguhnya terkandung dalam makna demokrasi dan keadilan sosial, yang artinya bahwa pendidikan dilakukan secara demokrasi sehingga tujuan yang diharapkan dapat terwujud dan pendidikan diperuntuhkan bagi kepentingan masyarakat dalam mencerdaskan kehidupan bangsa.

Pemerintah mengeluarkan peraturan baru yang termuat dalam Peraturan Menteri Pendidikan dan Kebudayaan Republik Indonesia Nomor 80 Tahun 2015 tentang petunjuk teknis penggunaan dan pertanggungjawaban keuangan dana bantuan operasional sekolah, dijelaskan pada pasal 1 bahwa biaya pendidikan adalah sumber daya keuangan yang disediakan dan diperlukan untuk biaya satuan pendidikan, biaya penyelenggaraan dan pengelolaan pendidikan, serta biaya pribadi peserta didik sesuai peraturan perundang-undangan. Kebijakan pendidikan saat ini menunjukkan desentralisasi (Camelia, et al, 2014). Dalam hal ini sekolah masih memungut biaya untuk operasional maka sekolah tersebut melakukan pelanggaran terhadap peraturan pemerintah sesuai dengan peraturan menteri pendidikan dan kebudayaan mengenai keuangan dana bantuan operasioanl sekolah.

Pemerintah Daerah memberikan kebebasan dan keringanan kepada masyarakat untuk wajib belajar 9 tahun tanpa ada pungutan biaya, hal tersebut sesuai dengan Peraturan Pemerintah Republik Indonesia Nomor 47 Tahun 2008 tentang wajib belajar. Hal tersebut juga terdapat dalam Peraturan Daerah Kabupaten Pekalongan Nomor 8 tahun 2014 tentang Penyelenggaraan Pendidikan.Akan tetapi hal tersebut belum sepenuhnya dilaksanakan dengan baik, karena masih adanya pungutan biaya kepada siswanya baik SD/MI maupun SMP/MTS untuk dana operasional sekolah. Pemerintah sudah memberikan dana untuk operasional kepada pihak sekolah berupa dana BOS, dana tersebut diberikan untuk membantu kepentingan operasional sekolah. Namun antara peraturan yang ada dengan apa yang terjadi dilapangan itu tidak sesuai, artinya bahwa pihak sekolah masih memungut biaya kepada siswanya guna membantu operasioanl sekolah seperti diminta iuran untuk membangun renovasi gedung sekolah yang rusak serta pembangunan pintu masuk sekolah.

Pemerintah Daerah mengeluarkan dana operasional tersebut setiap tahunnya sesuai dengan peraturan dana operasional sekolah dikeluarkan setiap triwulan sekali, hal tersebut agar masyarakat miskin bisa mengikuti program belajar dengan baik. Dengan adanya dana tersebut masyarakat beranggapan bahwa tidak akan ada pungutan biaya lagi untuk sekolah, karena sudah adanya bantuan Pemerintah untuk program wajib belajar yang sesuai dengan Peraturan Pemerintah tersebut. Akan tetapi hal tersebut belum seluruhnya dilaksanakan oleh pihak sekolah. Berdasarkan dari uraian diatas maka dapat dilakukan sebuah riset tentang "Implementasi Kebijakan Pungutan Biaya Pendidikan di Era Otonomi Daerah". Fokus dalam penelitian ini adalah Kebijakan pemerintah daerah pada anggaran khusus pendidikan di Kabupaten Pekalongan. Adanya pungutan biaya liar yang terjadi pada pembiayaan pendidikan Kabupaten Pekalongan.Bagaimana pemerintah daerah menindaklanjuti adanya pungutan biaya liar pada pendidikan di kabupaten pekalongan. Penelitian ini bertujuan untuk untuk mengetahui kebijakan pemerintah terhadap pembiayaan pendidikan pada era otonomi daerah.

Penelitian ini untuk mengetahui dan menjelaskan implementasi pada keuangan daerah mengenai pungutan biaya pendidikan dikabupaten Pekalongan.

Adapun beberapa landasan teori yang di gunakan yakni :

\section{Kebijakan}

Hoogwood dan Gunn (2012) dalam artikel Kamaruddin, membagi kebijakan dalam dua kategori, yaitu: 1. Non implimentation, yaitu suatu kebijakan yang tidak dilaksanakan sesuai dengan 
rencana. 2. Unsuccseeful implimentation, biasanya terjadi manakala suatu kebijakan telah dilaksanakan sesuai dengan rencana, namun mengingat kondisi eksternal ternyata tidak menguntungkan.

\section{Otonomi Daerah}

Menurut Wayong dalam Hasbullah (2010:7) otonomi daerah adalah kebebasan untuk memelihara dan memajukan kepentingan khusus daerah, dengan keuangan sendiri, menentukan hukium sendiri, dan pemerintahan sendiri. Sedangkan otonomi daerah menurut Undang-Undang Republik Indonesia Nomor 23 Tahun 2014, adalah hak, wewenang dan kewajiban daerah otonom untuk mengatur dan mengurus sendiri urusan pemerintahan dan kepentingan masyarakat setempat dalam sistem Negara Kesatuan Republik Indonesia.

\section{Pendidikan}

Pendidikan sangat penting bagi manusia untuk mengembangkan potensi kemampuannya hal ini sesuai dengan pendapat Brubacher dalam Suwarno (2008:20) pendidikan adalah proses pengembangan potensi, kemampuan, dan kapasitas manusia yang mudah dipengaruhi oleh kebiasaan, kemudian disempurnakan dengan kebiasaankebiasaan yang baik, didukungan dengan alat (media) yang disusun sedemikian rupa, sehingga pendidikan dapat digunakan untuk menolong orang lain atau dirinya sendiri dalam mencapai tujuan-tujuan yang telah ditetapkan.

\section{Pungutan Biaya Pendidikan}

Menurut Peraturan Menteri Pendidikan dan Kebudayaan Republik Indonesia Nomor 44 Tahun 2012 mengenai pungutan dan sumbangan biaya pendidikan pada satuan pendidikan dasar yang didalamnya menjelaskan bahwa pungutan adalah penerimaan biaya pendidikan baik berupa uang dan/atau barang/jasa pada satuan pendidikan dasar yang berasal dari peserta didik atau orang tua/wali secara langsung yang bersifat wajib, mengikat, serta jumlah dan jangka waktu pungutannya ditentukan oleh satuan pendidikan dasar. Sedangkan sumbangan adalah penerimaan biaya pendidikan baik berupa uang dan/atau barang/jasa yang diberikan oleh peserta didik, orang tua/wali, perseorangan atau lembaga lainnya kepada satuan pendidikan dasar yang bersifat sukarela, tidak memaksa, tidak mengikat, dan tidak ditentukan oleh satuan pendidikan dasar baik jumlah maupun jangka waktu pemberiannya. Biaya pendidikan yang merupakan biaya yang dikeluarkan pemerintah untuk alokasi pendidikan pada suatu daerah, biaya tersebut meliputi biaya operasional sekolah (BOS), BSM, dan AKREDITASI. Pemerintah memberikan dana-dana tersebut guna upaya peningkatan mutu pendidikan dan meringankan beban biaya pendidikan bagi masyarakat untuk mendapatkan pendidikan yang lebih berkualitas, maka dari itu pemerintah daerah mengalokasikan biaya operasional tersebut.

\section{METODE PENELITIAN}

Dasar penelitian ini menggunakan metode Deskriptif kualitatif. "Metode Kualitatif yaitu metode penelitian yang berlandaskan pada filsafat postpositivisme, digunakan untuk meneliti pada kondisi obyek yang alamiah, (sebagai lawannya adalah eksperimen) dimana peneliti adalah sebagai instrumen kunci, pengambilan sampel sumber data dilakukan secara purposive dan snowbaal, teknik pengumpulan dengan trianggulasi (gabungan), analisis data bersifat induktif/kualitatif, dan hasil penelitian kualitatif lebih menekankan makna dari pada generalisasi(Sugiyono2013:15). Tujuan yang hendak dicapai dalam penelitian ini adalah untuk mengetahui dan mendeskripsikan pungutan biaya yang dilakukan oleh sekolah karena melanggar peraturan pemerintah, hal tersebut terjadi disekolah Desa Pododadi Kecamatan Karanganyar Kabupaten Pekalongan.Penelitian Kualitatif memungkinkan pencarian fakta dengan interpretasi yang tepat, memungkinkan mengkaji masalah-masalah normatif sekaligus memaparkan temuan dilapangan. Lokasi penelitian ini terletak dimana terdapat sekolah di desa Pododadi kecamatan Karanganyar Kabupaten Pekalongan yang masih melakukan pungutan biaya pendidikan liar dan Dinas Pendidikan Kabupaten pekalongan sebagai penanggung jawab kebijakan mengenai pendidikan. Sumber data dalam penelitian ini menggunakan data primer, atau data yang diambil secara langsung melalui wawancara dan data sekunder. Dalam penelitian ini yang dijadikan 
sumber data atau studi kasus penelitian yaitu sekolah SD N 02 Pododadi Kecamatan Karanganyar Kabupaten Pekalongan.

Teknik pengumpulan data dalam penelitian ini yang pertama wawancara secara semi terstruktur dengan narasumber. Dengan wawancara ini informasi tentang data-data yang berhubungan dengan sekolah, pemerintah daerah dan lain-lain. Para inform yang bersedia diwawancarai dengan purposive sampling dan swobaal pembiayaan pendidikan yaitu komite sekolah,kepala sekolah, guru, orang tua siswa. Wawancara dilakukan peneliti secara langsung, yang bertujuan untuk memperoleh data dari sekolah SD N 02 Pododadi Kecamatan Karanganyar Kabupaten Pekalongan tentang pungutan biaya pendidikan. Dokumentasi dilakukan saat peneliti terjun langsung untuk melakukan penelitian di Desa Pododadi Kecamatan Karanganyar Kabupaten Pekalongan. Segala proses yang dilakukan saat penelitian akan didokumentasi foto untuk mendapatkan data dan informasi yang kredibel. Melalui metode dokumentasi akan lebih memudahkan peneliti dalam mengolah hasil penelitiannya.

\section{HASIL DAN PEMBAHASAN}

\section{Implementasi Kebijakan Pembiayaan dana BOS disekolah SD N 02 Pododadi Kabupaten Pekalongan}

Teori Hoogwood dan Gunn menjelaskan bahwa kebijakan dibagi menjadi dua kategori, yaitu: 1. Non Implementation, yaitu suatu kebijakan yang tidak dilaksanakan sesuai dengan rencana. 2 . Ussuccseeful implementation, biasanya terjadi manakala suatu kebijakan telah dilaksanakan sesuai dengan rencana, namun mengingat kondisi eksternal ternyata tidak menguntungkan. Hal ini sesuai dengan kebijakan mengenai pembiayaan BOS yang pelaksanaanya sesuai dengan rencana laporan juknis yang telah dibuat oleh pemerintah pusat, akan tetapi ada faktor eksternal yang terjadi yaitu adanya pungutan biaya yang terjadi di sekolah. Kebijakan yang terdapat didalam juknis dana BOS sebagai operasional sekolah, dan adanya larangan pungutan biaya bagi sekolah. Akan tetapi dengan adanya dana
BOS tersebut sebagai operasioanl, sekolah masih meminta sumbangan kepada orang tua yang dilakukan bersifat memaksa. Hal ini disebabkan adanya pelaksanaan kebijakan yang kurang baik (jelek). Sehingga masih adanya Pembiayaan pendidikan sekolah yang merupakan biaya langsung meliputi dana BOS, hal ini seperti teori yang dikemukakan Gaffar dalam Supriadi (2010:4) pembiayaan pendidikan yang dibagi menjadi dua yaitu biaya langsung (direct cost) dan biaya tidak langsung (indirect cost). Penyaluran dana BOS yang dilakukan triwulan sekali ini sudah sesuai dengan apa yang dikehendaki, baik oleh sekolah maupun pihak pemerintah daerah. Dana tersebut digunakan sebaik-baiknya oleh sekolah untuk proses pendidikan. Dana BOS diberikan dengan menggunakan transfer rekening ke sekolah langsung, tidak melalui pemerintah daerah melainkan dari pusat ke provinsi kemudian langsung transfer ke sekolah penerima masing-masing. Pemerintah daerah kabupaten/kota hanya mengawasi sekolahsekolah yang menerima bantuan tersebut. Sehingga penyaluran bantuan ini sudah terealisasi dengan baik tanpa adanya pemotongan dari pihak mana pun karena sudah langsung sekolah tersebut yang menerima, akan tetapi masih adanya sumbangan yang sifatnya mengikat di sekolah SD N 02 Pododadi. Laporan kepada pemerintah daerah juga sudah berjalan dengan baik dilakukan sekolah sesuai dengan ketentuan pelaporan, sehingga tidak ada hambatan dalam penyaluran dana BOS karena sudah sesuai dengan ketentuan yang berlaku. Dalam hal ini sekolah juga mengelola bantuan tersebut secara mandiri dengan melibatkan dewan guru dan komite sekolah. Pengelolaannya juga harus secara profesional dengan menerapkan prinsip efisien,efektif, akuntabel dan transparan. Sekolah harus membuat laporan pemerimaan dan pengeluaran BOS untuk setiap triwulannya dan dilaporkan kepada pemerintah daerah setempat.

Penyaluran dana BOS yang dilakukan setiap triwulan sekali merupakan pembiayaan untuk operasi sekolah gratis yang rutin dilakukan untuk pendidikan. Hal ini sesuai dengan buku petunjuk penggunaan dan pertanggungjawaban dana BOS 
(Kemendikbud, 2015:6). Hal tersebut juga didukung oleh penelitian terdahulu oleh Lian (2012:82) yang menjelaskan bahwa penyaluran dana BOS dilakukan setiap triwulan. Dana tersebut sudah sesuai dengan prosedur yang ada baik penyalurannya maupun penggunaannya sesuai dengan ketentuan pemerintah, sehingga dana BOS sudah terealisasi dan berjalan dengan baik dan lancar. Dana BOS digunakan untuk pendanaan sekolah dasar guna untuk meringankan beban pembiayaan bagi masyarakat. Sesuai dengan Peraturan Menteri Pendidikan dan Kebudayaan Republik Indonesia nomor 80 Tahun 2015 yang menjelaskan tentang petunjuk teknis penggunaan dan pertanggungjawaban keuangan dana bantuan operasional sekolah, yang didalamnya terkandung bahwa untuk membantu pemerintah daerah mewujudkan peningkatan mutu pendidikan dan meringankan beban biaya pendidikan bagi masyarakat untuk mendapatkan pendidikan yang lebih berkualitas, maka pemerintah mengalokasikan dana bantuan operasional sekolah. Selain itu juga terdapat beberapa ketentuan dalam penggunaan BOS dan implementasi mengenai BOS yang menjelaskan mengenai kriteria sekolah untuk penerima BOS serta program penggunaan dalam manajemen sekolah yaitu Manajemen Berbasis Sekolah (MBS), di dalam Peraturan Menteri juga terdapat organisasi pemerintah yang merupakan tim pengelola dana BOS.

Melalui program BOS merupakan salah satu program menuntaskan wajib belajar 9 tahun pendidikan. Dengan adanya kesadaran masyarakat akan pentingnya pendidikan dan adanya program wajib belajar gratis maka para peserta didik semakin giat dalam belajar jika dibandingkan dengan dulu sebelum adanya program BOS tersebut. Kualitas akan pendidikan yang ada semakin maju, Sehingga dengan adanya partisipasi masyarakat sekitar juga tinggi akan pendidikan sehingga meningkatkan mutu pendidikan sekolah di SD N 02 Pododadi, hal tersebut berakibat semakin menurunnya anak putus sekolah. Dengan adanya program BOS juga menjadi sarana penting untuk meningkatkan akses pendidikan dasar yang bermutu. Sesuai dengan visi sekolah yaitu berprestasi, terampil dan berakhlak mulia siswa didiknya mempunyai kelebihan prestasi untuk menghadapi daya saing dalam pendidikan selanjutnya. Akan tetapi mutu disekolah ini juga mengalami peningkatan dibandingkan sebelum adanya pendanaan BOS tersebut.

Ketentuan bagi satuan pendidikan penerima bantuan operasional sekolah yaitu sekolah yang sudah terdata dalam sistem data pokok kependidikan dasar yang wajib menerima BOS. Sekolah SD N 02 Pododadi menerima bantuan BOS dengan setiap siswa mendapatkan untuk operasional, sehingga siswa sekolah dasar ini tidak membayar biaya operasioanl sekolah karena sudah adanya pembiayaan oleh pemerintah dengan dana BOS. Sekolah SD N 02 Pododadi menerima dana BOS yang seharusnya sekolah tidak boleh melakukan adanya pungutan biaya kepada orang tua, yang diperbolehkan oleh sekolah hanya meminta sumbangan. Dana BOS yang ada di sekolah sangat membantu adanya kemajuan sekolah baik mutu maupun kualitas sekolah. adanya dana BOS tersebut sekolah menjamin agar siswa yang lulus dapat melanjutkan ke sekolah tingkat SMP. Sekolah SD N 02 Pododadi selalu melakukan evaluasi diri, dan juga memiliki laporan rencana kegiatan dan anggaran sekolah (RKAS) untuk setiap tahunnya sebagai laporan wajib sekolah mengenai penggunaan dana BOS. Dalam pembuatan laporan RKAS sekolah merapatkan dengan komite sekolah dan juga disahkan oleh SKPD pendidikan kabupaten/ kota. Sekolah dalam menerapkan dana BOS sudah sesuai dengan petunjuk penggunaan yang dibuat oleh pemerintah.

Pembangunan maupun renovasi gedung sekolah merupakan kegiatan yang membutuhkan pembiayaan yang cukup banyak. Pembiayaan ini berasal dari pemerintahan yang bertanggung jawab dalam pembangunan fisik sekolah yaitu keuangan yang bersifat Dana Alokasi Khusus untuk pendidikan. Dan BOS serta DAK yang diperoleh dari APBN ini diberikan kepada pemerintah daerah untuk digunakan sebagai kebutuhan yang ada seperti untuk operasional sekolah dan pembangunan gedung sekolah di SD N 02 Pododadi. Akan tetapi 
Dana Alokasi Khusus untuk penyalurannya kurang ditanggapi oleh pemerintah yang artinya untuk pembiayaannya kurang maksimal. Sekolah yang mengalami kerusakan sudah seharusnya diperbaiki, akan tetapi setelah sekolah mengajukan persyaratan untuk biaya proses renovasi tersebut tanggapan dari pemerintah yang kurang tegas atau kurangnya respon dari pemerintah. Sedangkan sekolah yang sudah tidak layak dipakai itu sudah harus di renovasi, sedangkan biaya yang membutuhkan proses lama mengakibatkan gedung semakin parah. Dalam hal ini seharusnya pemerintah harus lebih tanggap dalam menanggapi hal seperti ini karena merupakan hal yang terpenting dalam pendidikan. Dengan adanya gedung yang nyaman akan membuat murid lebih giat dalam belajar, tidak terganggu oleh adanya kurang nyaman tempat belajarnya. Tanggapan pihak yang berwenang dalam pengalokasian DAK harus memaksimalkan proses pengeluaran bantuan yang tidak membutuhkan watu yang lama. Hal ini merupakan tanggung jawab dari Menteri Keuangan yang mengalokasikan DAK tersebut.

Keuangan daerah yang digunakan dalam pembiayaan pendiidkan, keuangan tersebut diantaranya yaitu DAK (Dana Alokasi Khusus) digunakan sebagai biaya untuk pendidikan yaitu dalam pembangunan fisik sekolah. DAK yang berasal dari APBN ini diberikan kepada pemerintah daerah untuk pendidikan, kebutuhan yang terkait dengan pendidikan yang ada seperti halnya dalam pembangunan gedung sekolah maupun kebutuhan renovasi sekolah. Akan tetapi hal ini pemerintah menanggapinya kurang tegas atau kurangnya tanggapan dari pemerintah yang cepat. Sehingga menyebabkan banyak kendala yang dialami oleh sekolah ketika ingin merenovasi sekolahnya. Dalam hal ini seharusnya pemerintah menanggapi dengan tegas guna meningkatkan sarana prasarana sekolah. Dalam pembangunan pendidikan ini salah satu yang menjadi permasalahan yaitu pemerintah kurang tanggap dalam pendanaan (dana) $\mathrm{Hal}$ ini didukung oleh pernyataan Hasbullah (2006:25) yang menyatakan bahwa persoalan dana merupakan persoalan yang paling krusial dalam perbaikan dan pembangunan sistem pendidikan di Indonesia dan dana juga merupakan salah satu syarat atau unsur yang sangat menentukan keberhasilan penyelenggaraan pendidikan. Selama ini dikeluhkan bahwa mutu pendidikan nasional rendah karena dana yang kurang, anggaran untuk pendidikan masih terlalu rendah. Padahal kalau mau bagaimana mereka membangun, justru mereka berani menempatkan anggaran untuk pembiayaan pendidikan melebihi keperluan-keperluan yang lain.

$$
\text { Dalam Sistem Pendidikan Nasional }
$$

sebenarnya sudah mengamanatkan tentang pentingnya alokasi anggaran dana untuk pembiayaan dan pembangunan pendidikan. Hal ini pemerintah daerah setempat harus memaksilmalkan penyaluran anggaran untuk perbaikan dan pembangunan pendidikan yang ada seperti dalam pembangunan gedung sekolah yang seharusnya ditanggapi dengan cepat karena merupakan sarana dalam pendidikan. Seperti halnya dana yang digunakan untuk alokasi sekolah yang diberikan oleh pemerintah daerah untuk kepentingan sekolah. Pemerintah daerah setempat seharusnya tanggap dan mengamati adanya permasalahan yang ada di daerahnya.

\section{Implementasi Kebijakan Pungutan Biaya Pendidikan di SD N 02 Pododadi Kabupaten Pekalongan.}

Hoogwood dan Gunn menjelaskan teori kebijakan yang didalamnya terdapat Non implementation, yaitu suatu kebijakan yang tidak dilaksanakan sesuai dengan rencana. Sekolah yang akan meminta sumbangan kepada orang tua, akan tetapi seharusnya sumbangan yang dilakukan tidak dengan memaksa dan terikat, namun sekolah ini melakukan sumbangan tersebut bersifat memaksa sehingga yang terjadi bukan sumbangan akan tetapi pungutan. Sekolah dalam melakukan pungutan ini dilakukan hanya dengan rapat kepala sekolah dan guru yang ada, dari komite sekolah tidak ikut serta dalam rapat tersebut sehingga pungutan tidak diketahui oleh komite sekolah dan juga dinas daerah yang terkait. Akan tetapi hanya kelapa sekolah, guru dan orang tua murid yang hadir dalam rapat yang diselnggarakan oleh sekolah. Orang tua yang telah 
diminta iuran hanya menulis nama siswa dan orang tuanya di selembar kertas yang hanya sebagai tanda hadirnya dalam rapat dan melakukan pembayaran yang telah ditentukan oleh sekolah atas kesepakatan kepala sekolah dan guru. Sehingga rapat ini bersifat tertutup baik dari komite sekolah maupun dinas daerah. Pungutan yang dilakukan oleh sekolah sebesar RP 50.000 dengan jumlah siswa 32 yang digunakan untuk memperbaiki sekolah yang rusak.

Pungutan memiliki beberapa kriteria, maka ada beberapa sekolah yang diperbolehkan untuk melakukan pungutan, diantaranya: 1 . sekolah negeri yang ingin meningkatkan mutu dan kualitas pendidikan di sekolah akan tetapi dana yang diberikan oleh pemerintah tidak mencukupi sehingga sekolah diperbolehkan memungut dari orang tua, hal ini biasanya terjadi pada sekolah yang letaknya tepat dikota. 2. Sekolah yang memang tidak cukup hanya mengandalkan dana BOS saja untuk mencukupi kebutuhan yang belum terpenuhi di sekolah. 3. Sekolah yang membutuhkan anggaran dana karena kurang tanggapnya pemerintah dalam pengalokasian anggaran dana pendidikan. 4. Sekolah yang letaknya dipedesaan sehingga sulit pemerintah untuk memberikan anggaran dana untuk pendidikan, maka sering terjadi keterlambatan pengiriman anggaran sehingga sekolah diperbolehkan memungut kepada orang tua. 5 . Sekolah mengalami kerusakan gedung dan sudah mengajukan anggaran beberapa kali permohonan untuk memperbaiki akan tetapi dana yang ada pemerintah kurang mendapat tanggapan yang cepat, sedangkan sekolah sudah mengalami kerusakan sehingga mengganggu akan pembelajran di sekolah, maka sekolah diperbolehkan untuk meminta sumbangan kepada orang tua atau pihak lain. Dalam hal ini sekolah SD N 02 Pododadi meminta sumbangan kepada orang tua yang digunakan untuk memperbaiki gedung yang rusak dikarenakan sekolah yang mengajukan kepada pemerintah untuk anggaran pembangunan membutuhkan waktu lama dalam memproses sehingga sekolah mempunyai kriteria dalam memungut biaya kepada orang tua. Hal tersebut dikarenakan gedung yang digunakan tersebut sudah tidak layak sehingga membutuhkan perbaikan. Anggaran dana sekolah yang kurang sehingga sekolah diperbolehkan memungut kepada orang tua, karena sekolah tersebut termasuk dalam kriteria sekolah yang boleh melakukan pungutan dikarenakan sekolah kekurangan dana untuk memperbaiki gedung sekolah yang sudah tidak layak tersebut.

Mekanisme terjadinya sumbangan di sekolah bermula dari adanya laporan RAKS yang dibuat oleh kepala sekolah, guru, komite sekolah berdasarkan triwulan juknis. Dalam rapat awal tahun biasanya sekolah menghadirkan orang tua untuk memaparkan mengenai laporan RAKS tersebut yang didalamnya terdapat dana BOS yang masih kurang. Adanya rapat tersebut sekolah memaparkan program atau kegiatan yang akan dilakukan oleh sekolah dalam 1 tahun. Rapat tahunan sekolah tidak dihadiri oleh dinas UPTD kecamatan yang seharusnya memberikan sosialisasi mengenai dana BOS dalam RAKS. Dalam RAKS juga membahas mengenai adanya sumbangan sukarela, yang sifatnya tidak memaksa, waktu dan nominal tidak ditentukan oleh sekolah. akan tetapi yang terjadi disekolah ini antara waktu dan nominal ditentukan oleh sekolah yaitu sebesar Rp 50.000 dengan jumlah siswa 32 , dan waktu pembayaran hanya 1 bulan. Sekolah dalam melakukan sumbangan tersebut tidak adanya bukti otentik tertulis oleh sekolah dan tidak terdapat dalam laporan RAKS yang seharusnya ditulis. Sumbangan tersebut juga seharusnya ditulis dalam laporan RAPBS akan tetapi sekolah ini tidak menulis sumbangan di dalam laporannya dan sekolah harus merapatkan kembali laporan RAKS diakhir tahun dengan stakeholder pendidikan.

Adanya peraturan larangan pungutan untuk biaya pendidikan tersebut dilatar belakangi oleh maraknya pungutan yang dilakukan pihak sekolah terhadap peserta didik (orang tua peserta didik) yang dilakukan melalui ketetapan komite sekolah. Jenis pungutan yang dilakukan oleh pihak sekolah yaitu pungutan biaya pembangunan gedung untuk memperbaiki ruang kepala sekolah serta pembangunan untuk pintu gerbang masuk ke sekolah. Dengan adanya peraturan mengenai 
larangan pungutan sekolah melakukan pungutan karena sekolah sudah termasuk dalam kriteria sekolah yang diperbolehkan melakukan pungutan. Hal ini yang harus ditindaklanjuti dengan tegas lagi oleh pemerintah daerah bahwa sekolah yang boleh melakukan pungutan adalah sekolah yang memenuhi kriteria dalam memungut kepada orang tua, seperti sekolah SD N 02 Pododadi diperbolehkan melakukan pungutan karena sekolah yang lambat mendapatkan alokasi dana untuk perbaikan gedung, sehingga jika gedung tidak segera diperbaiki akan mengganggu proses pembelajaran sekolah. Pungutan yang terjadi pada sekolah atas dasar kesepakatan orang tua, akan tetapi sekolah tidak melaporkan besaran pungutan tersebut kepada pemerintah daerah. Pungutan yang terjadi digunakan untuk perbaikan sekolah, sekolah tidak melanggar peraturan yang ada karena sekolah sudah memenuhi kriteria dalam sekolah yang diperbolehkan untuk melakukan pungutan.

Adanya pungutan biaya pendidikan yang terjadi pada sekolah dasar yang berlokasi dipedesaan ini telah ada dalam Peraturan Menteri Pendidikan dan Kebudayaan yang seharusnya sekolah tidak melakukan pungutan kepada orang tua siswa akan tetapi hanya boleh melakukan sumbangan. Seharusnya sekolah meminta sumbangan dengan sukarela tidak dengan memaksa antara nominal dan waktunya ditentukan oleh sekolah dan tidak dengan laporan yang jelas sumbangan yang terjadi di sekolah. Adanya Peraturan Menteri Pendidikan dan Kebudayaan Republik Indonesia Nomor 44 Tahun 2012 yang menjelaskan tentang pungutan dan sumbangan biaya pendidikan pada satuan pendidikan dasar, yang terkandung didalamnya menjelaskan yaitu pungutan adalah penerimaan biaya pendidikan baik berupa uang dan/atau barang/jasa pada satuan pendidikan dasar yang berasal dari peserta didik atau orang tua/wali secara langsung yang bersifat wajib, mengikat, serta jumlah dan jangka waktu pemungutannya ditentukan oleh satuan pendidikan dasar. Akan tetapi jika sumbangan adalah penerimaan biaya pendidikan baik berupa uang dan/atau barang/jasa yang diberikan oleh peserta didik, orang tua/ wali, perseorangan atau lembaga lainnya kepada satuan pendidikan dasar yang bersifat sukarela, tidak memaksa, tidak mengikat, dan tidak ditentukan oleh satuan pendidikan dasar baik jumlah maupun jangka waktu pemberiannya. Dalam hal ini sekolah hanya boleh melakukan pungutan kepada peserta didik, orang tua/ wali pada satuan pendidikan dikarenakan sekolah memenuhi kriteria yang diperbolehkan melakukan pungutan. Hal ini terdapat dalam penelitian terdahulu oleh Lian (2012:81) bahwa pungutan terjadi di sekolah yang sudah mendapatkan dana dari pemerintah berupa block grant dari APBD akan tetapi dana tersebut masih kurang sehingga sekolah memungut iuran kepada orang tua untuk menutupi kebutuhan sekolah. Dan sekolah menghadapi hambatan dalam proses belajar mengajar serta memberatkan beban orang tua.

Hal ini juga tertuang dalam Peraturan Menteri Pendidikan dan Kebudayaan Republik Indonesia Nomor 60 Tahun 2011 pasal 4 yaitu: (1) Sekolah yang diselenggarakan oleh masyarakat tidak boleh melakukan pungutan, yang dikaitkan dengan persyaratan akademik untuk penerimaan peserta didik, penilaian hasil belajar peserta didik, dan/atau kelulusan peserta didik. Untuk mensejahterakan anggota komite sekolah atau lembaga representasi pemangku kepentingan sekolah. (2) Sekolah yang diselenggarakan oleh masyarakat dilarang melakukan pungutan kepada peserta didik, orang tua, atau walinya yang tidak mampu secara ekonomis.

Pemerintah telah berupaya untuk mengatasi permasalahan pendidikan dengan memberikan dana Bantuan Operasional Sekolah (BOS), yang dimaksudkan untuk meringankan beban biaya sekolah terutama bagi masyarakat yang kurang mampu.

Adanya penggunaan dana BOS saja sekolah tidak mencukupi untuk operasional di sekolah, maka sekolah mengajak orang tua untuk memberikan sumbangan yang bersifat sukarela, akan tetapi pelaksanaan sumbangan di sekolah masih belum sesuai dikarenakan masih terikat antara nomimal dan waktu sumbangan tersebut ditentukan oleh sekolah, maka hal ini lah yang tidak diperbolehkan 
dalam sumbangan biaya sekolah. Sehingga sekolah untuk memajukan pendidikannya diperbolehkan adanya sumbangan dari orang tua akan tetapi harus sesuai dengan peraturan menteri yang ada. Sekolah tidak ada pungutan jika dalam meminta sumbangan kepada orang tua sudah sesuai dengan aturan yang telah ditentukan. Akan tetapi sekolah memnuhi kriteria dalam memungut sehingga diperbolehkan. Sekolah harus memahami adanya sumbangan dengan pungutan yang terjadi pada biaya pendidikan sesuai dengan kriteria yang ada pada pungutan. Sekolah yang melakukan pungutan dengan cara mengadakan rapat orang tua siswa yang hanya dihadiri oleh kepala sekolah dan guru akan tetapi tidak melibatkan komite sekolah serta pemerintah daerah yang memberikan sosialisasi adanya penggunaan dana BOS, akan tetapi dalam rapat sekolah melakukan iuran yang nominalnya ditentukan oleh sekolah sebesar RP 50.000 setiap siswanya dan dengan jangka waktu yang telah ditentukan oleh sekolah tanpa adanya kesepakatan antara komite sekolah, kepala sekolah, guru maupun orang tua siswa. Sehingga iuran tersebut bukan merupakan sumbangan melainkan pungutan, hal tersebut di perbolehkan karena sekolah memenuhi kriteria pungutan.

Beberapa kendala yang dialami sekolah akibat terjadinya pungutan biaya, adanya proses pembangunan di sekolah yang merupakan tanggung jawab pemerintahan kini kurang adanya respon. Sehingga dalam hal ini pihak sekolah meminta sumbangan dari orang tua siswa untuk membantu merenovasi gedung yang sudah tidak layak dipakai. Adanya proses pengajuan bantuan untuk alokasi pembangunan yang membutuhkan waktu lama dalam prosesnya, hal ini lah yang membuat sekolah meminta sumbangan kepada orang tua siswa akan tetapi cara sekolah untuk meminta sumbangan itu yang kurang tepat. Seharusnya tidak boleh menentukan nominal dan batas waktu pembayaran yang mengakibatkan itu menjadi pungutan yang hanya kesepakatan dari komite sekolah. Seharusnya pemerintah dalam keuangan alokasi untuk pembangunan tanggap secara cepat untuk terselenggaranya kegiatan renovasi gedung dan tidak mengganggu proses pembelajran di sekolah.

Kendala yang terjadi saat proses bantuan untuk perbaikan dan pembangunan gedung sekolah terjadi lama maka berakibat sekolah memungut biaya kepada peserta didik atau orangtua/wali yang digunakan untuk perbaikan dan pembangunan tersebut. Akan tetapi sekolah diperbolehkan dalam memungut karena memenuhi kriteria dalam melakukan pungutan. Hal ini akan berdampak pada orang tua/ wali peserta didik yang mereka berpenghasilan sedikit yang hanya digunakan untuk kebutuhan makan sehari-hari sehingga mereka tidak dapat atau merasa keberatan untuk membayar biaya sekolah tersebut. Padahal selama ini masyarakat berfikir bahwa pendidikan dasar itu sudah gratis semua tanpa adanya biaya yang ditentukan oleh sekolah sendiri. Terutama pungutan ini berdampak pada penerimaan siswa baru yang biasanya diminta untuk membayar uang pembangunan. Sekolah yang kekurangan dalam pendanaan pembangunan akibat kurangnya partisipasi pemerintah dalam pembiayaan pendidikan. Pendidikan yang ada di daerah pedesaan ini kurang mendapatkan perhatian dari pemerintah daerahnya sehingga sarana yang kurang memadai untuk sekolah berakibat permasalahan yang tidak di inginkan oleh pemerintah seperti terjadinya pungutan tersebut. Masyarakat yang ekonominya rendah juga tidak sanggup untuk membayar pungutan tersebut, merasa terbebani adanya pendidikan dasar yang membayar biaya pembangunan.

Kendala lain yang terjadi selain dalam pembangunan sekolah yang menghambat proses pembelajaran juga terjadi pada tenaga pengajar yang sangat kekurangan bagi sekolah dasar. Kurangnya biaya untuk sekolah sehingga sekolah meminta sumbangan juga terjadinya kekurangan guru pengajar membuat proses pembelajaran dalam sekolah kurang efisien. Masih banyaknya guru honorer di sekolah ini sehingga kurangnya biaya untuk membayar, hal ini dilihat dari sekolah dasar yang ada sekitar 518 sekolah yang setiap 1 sekolah membutuhkan 9 guru akan tetapi sekolah yang biasanya kurang dari 9 guru yang sudah PNS, 
sekurangnya sekolah harus mengambil guru pengabdian yang harus membiayai sendiri untuk mengajar. Guru untuk yang mengabdi saja harus dapat rekomendasi dari pemerintah, hal ini juga akan mempengaruhi kekurangannya anggaran pemerintah untuk pendidikan, karena harus membayar guru yang honorer.

Di Kabupaten Pekalongan ada sekitar 900 guru wiyata bakti yang harus dibiayai oleh provinsi dengan APBN maupun dana BOS, tetapi ada kriteria guru yang harus dipenuhi. Sehingga guru yang ada masih kurang sangat banyak mengakibatkan adanya guru wiyata bakti yang gajinya berupa honorer dari dana BOS. Masih sangat banyak membutuhkan untuk tenaga pengajar agar efisiensi mengajar tidak terhambat.

Kendala yang terjadi pada pendidikan dasar di SD N 02 Pododadi terutama pada tenaga pengajar yang kurang/minim, sehingga proses pembelajaran disekolah yang kurang efisien.

Banyaknya guru yang termasuk guru honorer juga semakin menambahnya biaya untuk membiayai, sebagai tambahan tenaga pengajar. Sekolah yang harus membiayai guru sebagai penambahan tenaga pengajar akan menambah pengeluaran pembiayaan pendidikan. Sehingga manajemen maupun proses pembelajaran sekolah menjadi kurang efektif dan efisien.

Hal ini tidak sesuai dengan pernyataan Hasbullah (2006:21) yang menyatakan bahwa seharusnya pendidikan yang maju harus memperhatikan kurikulum yang menunjang keberhasilan pendidikan di daerah. Seperti halnya sebuah lembaga pendidikan yang harus ditunjang hal-hal sebagai berikut: (1) Tersedianya tenaga pengaja yang memadai dan kompeten. (2) Tersedianya fasilitas fisik atau fasilitas belajar yang memadai dan menyenangkan. (3) Tersedianya fasilitas bantu untuk proses belajar mengajar. (4) Adanya tenaga penunjang pendidikan, seperti tenaga administrasi, pembimbing,pustakawan,laboran. (5) Tersedianya dana yang memadai. (6) Manajemen yang efektif dan efisien.

\section{SIMPULAN}

Berdasarkan data yang diperoleh, Implementasi Kebijaksaan Pungutan Biaya Pendidikan yang difokuskan pungutan dalam pembiayaan pendidikan di SD N 02 Pododadi Kecamatan Karanganyar Kabupaten Pekalongan. Telah di sajikan dan di bahas, maka dapat diambil kesimpulan sebagai berikut: (1) Sektor pendidikan dasar, terutama dalam pembiayaan pendidikan yang dialokasikan untuk siswa sekolah sebagai program wajib belajar 9 tahun yang ada di SD N 02 Pododadi. Pembiayaan dalam pendidikan masih mengandalkan dari APBN seperti dana BOS dan bantuan BKM. Dengan adanya program BOS dari pemerintah pusat maka pemerintah daerah hanya bertugas sebagai pengawas sekolah yang menerima BOS. Dengan program wajib belajar 9 tahun guna untuk peningkatan mutu pendidikan dasar maka sekolah dasar SD N 02 Pododadi menunjang program peningkatan mutu, sarana dan prasaran yang memadai. (2) Sekolah apabila hanya mengandalkan dana BOS tidak akan mencukupi untuk kemajuan sekolahnya. Oleh karena itu sekolah mengajak partisipasi orang tua siswa untuk memberikan sumbangan, guna mendukung proses pembelajaran sekolah. Namun sumbangan tersebut bersifat memaksa, ditentukan besaran dan waktunya.

Beberapa saran yang diperlukan yaitu : (1) Pihak sekolah hendaknya dalam melaksanakan rapat komite dengan mengundang pembicara dari Dinas Pendidikan daerah. Hal ini karena salah satu tugas dari tim manajemen BOS Kabupaten untuk melakukan sosialisasi/ pelatihan kepada sekolah, komite sekolah dan masyarakat tentang program dana BOS. Selain itu, Dinas Pendidikan dan Kebudayaan Kabupaten Pekalongan juga dapat mengawasi sekolah dalam penggunaan BOS secara langsung. (2) Pihak sekolah hendaknya dalam melaksanakan rapat mengenai keuangan sekolah yang terkait adanya pungutan atau sumbangan tidak boleh dilakukan oleh pihak kepala sekolah dan guru saja, melainkan harus adanya kesepakatan dari pihak komite sekolah, bupati/wali kota daerah serta 
orang tua/ wali peserta didik yang dirapatkan secara bersama dan transparan. (3) Sekolah dalam mengajak partisipasi masyarakat dalam bentuk sumbangan kepada orang tua siswa tidak boleh bersifat memaksa/mengikat yang nominal dan waktu pemberiannya ditentukan oleh sekolah, akan tetapi harus dengan sukarela orang tua yang memberi sumbangan untuk sekolah tersebut. (4) Sekolah seharusnya mendapat mengawasi secara tegas akan keuangan dalam pendidikan agar tidak terjadi pungutan liar pada sekolah yang bersifat memaksa/ mengikat kepada orang tua.

\section{DAFTAR PUSTAKA}

Arikonto, Suharsimi. 2010. Prosedur Penelitian. Jakarta: Rineka Cipta.

Camelia, Staiculescu, et al. 2014. The Impact of Decentralization on the Romanian School. Social and Behavioral Sciences, Volume 124, Pages 69-76.

Dimas. 2012. "Pelaksanaan Otonomi Daerah dalam Dunia Pendidikan". Artikel 24 Maret 2016.

Faguet, Jean Paul. 2014. Decentralization and Governance. World Development, Volume 53, Pages 2-13.

Hasbullah. 2006. Otonomi Pendidikan. Jakarta: PT Raja Grafindo Persada.

Kamaruddin, Hasan.2012. "Otonomi Daerah dan Pendidikan". Artikel 21 Maret 2016.

Laudams, Vairis. 2014. How Actors of Local Society (Community) Influence the Development of Decentralized General Education and Their Attitude to it. Social and Behavioral Sciences, Volume 140, Pages 570-575.

Lian,H.O.Tjun. 2012. Biaya Operasional Sekolah Dasar Negeri diDaerah Khusus Ibukota Jakarta. Jurnal: Perkotaan Vol. 4 No. 2 Desember 2012.

Marsus. 2011. Strategi Peningkatan Mutu di Era Otonomi Daerah. Jurnal: Medtek Vol. 3 No.2 Oktober 2011.

Peraturan Menteri Pendidikan dan Kebudayaan Republik Indonesia Nomor 44 Tahun 2012 tentang pungutan dan sumbangan biaya pendidikan pada satuan pendidikan dasar.

Peraturan Menteri Pendidikan dan Kebudayaan Republik Indonesia Nomor 60 Tahun 2011 tentang larangan pungutan biaya pendidikan pada sekolah dasar dan sekolah menengah pertama.

Peraturan Menteri Pendidikan dan Kebudayaan Republik Indonesia Nomor 80 Tahun 2015 tentang Pertanggung jawaban Keuangan Dana Bantuan Operasional Sekolah.

Peraturan Menteri Pendidikan dan Kebudayaan Republik Indonesia Nomor 60 Tahun 2011 tentang Larangan pungutan di Tingkat SD/MI dan SMP/MTs.

Peraturan pemerintah Daerah Nomor 8 Tahun 2014 tentang Penyelenggaraan pendidikan.

Peraturan Pemerintah Republik Indonesia Nomor 47 Tahun 2008 tentang Wajib Belajar.

Sugiyono. 2013. Metode Penelitian Pendidikan. Bandung: Alfabeta.

Sumaryadi, I, Nyoman. 2005. Efektivitas Implementasi Kebijakan Otonomi Daerah. Jakarta: CV Citra Utama.

Suwarno, Wiji. 2008. Dasar Dasar Ilmu Pendidikan. Yogyakarta: Ar-ruzz Media.

Undang-Undang Republik Indonesia Nomor 22 Tahun 1999 tentang Pemerintah Daerah.

Undang-Undang Republik Indonesia Nomor 32 Tahun 2004 tentang Pemerintahan Daerah.

Undang-Undang Republik Indonesia Nomor 23 Tahun 2014 Perubahan tentang Pemerintahan Daerah.

Undang-Undang Republik Indonesia Nomor 20 Tahun 2003 tentang Sistem Pendidikan Nasional.

Undang-Undang Nomor 9 Tahun 2015 tentang Perubahan Kedua Atas Undang-Undang Pemerintahan Daerah.

Website Kementrian Pendidikan dan Kebudayaan Republik Indonesia (25 Maret 2016, pukul 13.15)

Widjaja, HAW.2001. Otonomi Daerah dan Daerah Otonom. Jakarta: Rajawali Pers.

-impor-kedelai/41222. (11 Februari 2016). 